\title{
The occupational safety on the construction sites of the farm production buildings in Finland
}

\author{
M. Hellstedt, ${ }^{1}$ K.O. Kaustell, ${ }^{2}$ T. Kivinen ${ }^{3}$ \\ 1MTT Agrifood Research Finland, Animal Production Research, Seinäjoki; ${ }^{2}$ MTT Agrifood Research \\ Finland, Economic Research, Helsinki; ${ }^{3}$ MTT Agrifood Research Finland, Animal Production \\ Research, Helsinki, Finland
}

\begin{abstract}
The size of farms has increased considerably during Finland's EU membership. The growth has meant big investments in the new production buildings. The buildings have been switched to big industrialhall-like constructions from small-scale ones which have contained own timber and own work contribution. The objective of the project financed by Farmers' Social Insurance Institution was to improve occupational safety on farm building construction and renovation sites by disseminating current safety practices and by developing ways of action which are better than the prevailing ones. The project consisted of a literature review, statistical analysis, as well as a farmer and designer interviews.

In the statistical analysis the MATA occupational injuries insurance claims database on farmers' claims during construction and renovation work for the years 2005 - 2008 was compared with the register of Federation of Accident Insurance Institutions on the construction workers' injuries. In comparing the reasons of the accidents a clear difference was found; poor scaffoldings and ladders are still the main culprits on farm accidents.

Farmer interviews were used to assess occupational safety measures on the construction site, occurred injuries and their types, nearmiss situations and the underlying factors which have led to the injuries. Also construction safety deficiencies as well as the direct and indirect costs caused for instance because of the delay in completion of construction project were discussed. Designer interviews aimed to find out how occupational safety and health considerations are taken into account in farm building planning and counseling, and how this
\end{abstract}

Correspondence: Maarit Hellstedt, MTT Agrifood Research Finland, Animal Production Research, Kampusranta 9 C, 60320 Seinäjoki, Finland

E-mail: maarit.hellstedt@mtt.fi

Key words: construction; safety; production building; agriculture.

Acknowledgments: authors want to thank the Farmers' Social Insurance Institution (MELA) and MTT Agrifood research Finland for their financial support which made this project possible.

(c) Copyright M. Hellsted et al., 2013

Licensee PAGEPress, Italy

Journal of Agricultural Engineering 2013; XLIV(s2):e131

doi:10.4081/jae.2013.s2.e131

This article is distributed under the terms of the Creative Commons Attribution Noncommercial License (by-nc 3.0) which permits any noncommercial use, distribution, and reproduction in any medium, provided the original author(s) and source are credited. experience of the designers should be utilized in order to improve safety at the construction sites on farms.

Farmers knew their obligations on occupational safety poorly. The situation was further worsened by the fact that on the site the supervisor tasks were only nominally executed. The designers knew the occupational health and safety legislation better but this did not help the situation on the sites because designers are not generally involved in the actual implementation of the construction project.

\section{Introduction}

The number of farms has decreased but their size has increased considerably during Finlands EU membership. The growth has meant big investments in new production buildings. The buildings have been switched to big industrial-hall-like constructions from small-scale ones that have contained own timber and own work contribution.

The value of Agricultural production buildings is about 350 MEUR which is about $5 \%$ of the yearly value of whole construction sector in Finland (MMM 2013). Agricultural buildings form yearly 10\% of the whole constructed cubic meters in Finland and about $40 \%$ of the industrial-hall-like construction cubic meters. (Tilastokeskus 2013).

About 1500 different kind of construction projects are accomplished yearly. According to Latvala and Pyykoönen (2009) the average si ze of loose houses for milking cows during the last years has been $1400 \mathrm{~m}^{2}$ and $7850 \mathrm{~m}^{3}$ and the average costs have been about $800000 €$. The construction work is performed by building contractors, competent carpenter groups or by the farmers themselves.

In the beginning of the year 2003 a new law on occupational safety came in to force (Työturvallisuuslaki 2003). Based on the law a new act on occupational safety on construction sites was introduced in 2009 (VnA 2009). The aim of the new law is to enhance proactive occupational safety and hands-on safety control on working places. The act aims to clear the responsibilities each party on the construction site has.

The objective of this project was to improve occupational safety on farm building construction and renovation sites by disseminating curren $t$ safety practices and by developing ways of action which are better than the prevailing ones.

\section{Materials and methods}

The project consisted of a literature review, statistical analysis, as well as a farmer and designer interviews.

\section{Literature review, statistical analysis}

Both results of research projects on occupational safety on agricul- 
tural production building sites and other examples of good practices in Finland and in other countries were investigated and their usability in Finnish conditions was estimated. Also results of the latest domestic researches on occupational safety on construction sites were examined in order to find practices suitable for agricultural construction sites.

In the statistical analysis the MaTa occupational injuries insurance claims database on farmers' claims during construction and renovation work for the years 2005 - 2008 was used to determine the most common accidents occurred on farm construction sites and their reasons. The Mata database was also compared with the register of Federation of Accident Insurance Institutions from the same years (2005 - 2008) on the construction workers' injuries to find out the possible differences between the most common accidents between these two groups.

\section{Farmer and designer interviews}

Farmer interviews were carried out by visiting farms $(\mathrm{N}=8)$. The occupational safety measures on the construction site, the possible accidents which had happened and their types and underlying factors which had led to the accident were clarified with the farmer interviews. Also the near accident situations and the safety lacks of the construction work were discussed. Farmers were also asked about their knowledge on the occupational safety legislation and responsibilities on construction sites and their attitude towards safety issues.

Designer interviews $(\mathrm{N}=10)$ were made using a web poll. Through the designer int erviews it was clarified how the occupational safety issues are taken into consideration in the design of farm production buildings and how attention should be paid to the matter according to the designers' experience so that the occupational safety situation would become better.

\section{Results}

During the years 2005 - 2008 a total of 1205 accidents at farm construction work were registered in the Farmers' insurance database (MATA). The construction work accidents accounted for 5-6 \% of all the accidents occurred to farmers at their farm work yearly. The construction work accidents resulted in about 46500 days of disability, the average period of disability being 38.6 days. During the year 2008 the Farmers' Social Insurance Institution (Mela) paid out to farmers about 1.62 MEUR.

Most of these accidents at construction sites occurred at repairing and maintenance tasks (39.5\%), reconstruction and enlargement sites (18.6 \%) and construction of new production facilities (26.5 \%). The most common reason for accidents at the construction sites was falling and hitting against something (about $26 \%$ of the accidents). Other common reasons were contact to a cutting object like a knife or some other stabbing edge (11,5\%), and physical stress on muscular and skeletal bodies (10,8 \%).

When comparing the reasons of the accidents between the MATA database and the register of Federation of Accident Insurance Institutions (TVL) a clear difference was found; 'poor scaffoldings and ladders' are still the main reasons of farm accidents (18.2 \%) while at other construction sites they were ' Raw materials, goods, supplies, equipment etc.' (34.7\%) and ' The terrain (ice) roughness, slipperiness, deceptiveness, soil, obstructions '(18\%) (Table 1).

Farmers found the most hazardous cases at their construction sites to be roof works where tools could drop down or men could drop as well. Helmets were not popular due to hot summer days and thus too much sweating. Scaffoldings were often poor without safety railings. Too often ladders were used as scaffolds which led to accidents when ladders unexpectedly slid down. Lucky enough most workmen used safety boots. Lifting heavy loads caused muscle and bone injuries. Machinery installations caused minor injuries due to sharp metal edges.

According to the interviews the farmers knew their obligations of occupational safety rather poorly. The situation was further aggravated by the fact that on the site the site supervisor tasks including occupational safety issues were usually taken care by nominal and minimal effort and in most cases by the farmer himself. Special plans for occupational safety, which the legislation requires, were very rare. Although construction site meetings were held regularly on most farm construction sites (70\%), occupational safety issues were discussed seldom and normally only to remind the constructor of his responsibilities.

The designers knew the occupational health and safety legislation quite well. All the designers knew the law on Occupational safety (Työturvallisuuslaki 2003) although only $40 \%$ of them told that they knew it very well. $30 \%$ of the designers told that they know the Act on occupational safety at construction sites (VnA 2009) well and they take it into account with in their construction plans. However this did not help the situation on the sites because designers are not generally involved in the actual implementation of the construction project

\section{Discussion}

Accident risk is high at farm construction sites just like it is at all other construction sites. The culprits differ which is mainly caused by the fact that the farm construction sites are not arranged as professionally as they should from the point of view of their size. The legislation on occupational safety at construction sites, however, is the same for all types of construction sites without any exceptions. In the legislation, there are certain responsibilities and tasks for every worker and party.

Mäkelä (2006) has developed a conceptual system on the safety issues that have to be planned on every construction site. This kind

Table 1. Distribution of the culpits at the construction site for farmers (MATA) and for construction workers (TVL).

\begin{tabular}{|c|c|c|}
\hline Culpits & MATA \% & TVL $\%$ \\
\hline $\begin{array}{l}\text { The terrain (ice) roughness, slipperiness, } \\
\text { deceptiveness, soil, obstructions }\end{array}$ & 16.6 & 18.0 \\
\hline $\begin{array}{l}\text { Raw materials, goods, supplies, equipment, } \\
\text { the external environment, fences, loads, } \\
\text { tractor accessories and structures }\end{array}$ & 13.2 & 34.7 \\
\hline $\begin{array}{l}\text { Saws, circular saws, field saws, machine tools, } \\
\text { cutting machine, slicers, choppers, hand-operated } \\
\text { drills and grinding machinery, chain saws }\end{array}$ & 10.0 & 3.7 \\
\hline Hand tools & 9.2 & 8.6 \\
\hline $\begin{array}{l}\text { The external environment (conditions), the work } \\
\text { movements and work positions }\end{array}$ & 9.1 & 0.9 \\
\hline Other culpits & 7.6 & 5.5 \\
\hline Stairs & 5.2 & 2.6 \\
\hline Other buildings, structures and constructions & 5.1 & 0.3 \\
\hline
\end{tabular}


of procedure is not used at farm construction sites because farmers do not recognize the need for this kind of planning. This is partly due to the fact that they do not know well enough their responsibilities on occupational safety issues and partly due to the fact that they are used to do the construction work by themselves and they are not familiar with the procedures on construction sites with workers and constructors. Farmers also lack the information of possible risks at their construction site. It is very difficult to recognize the risks comprehensively. According to Carter and Smith (2006) this is based on lack of common information, knowledge of possible risks and coordinated management. It is possible to enhance risk analysis by using different kinds of checking lists which are available. But the problem still is that the farmers don't even know these checklists.

\section{Conclusions}

The direct costs paid out by the insurance company are only part of the total costs caused by the accidents at construction sites. The value of the possible delay of the whole project and the value of other indirect costs is very difficult to estimate. Oinonen \& Aaltonen (2007) have estimated that these indirect costs are normally much bigger than the direct costs. Therefore all efforts made to minimize the number of accidents at farm construction sites have a significant influence on the economy of the farm.

A possible solution for enhancing the occupational safety on farm construction sites is that the designers should be given a more visible role in the whole construction process. They have the needed knowledge which should be used for the best of all parties.
In order to get this development in practice, farmers should be given more accurate information on their responsibilities on occupation safety issues and also the economic benefits of the reduction of accidents on their farm construction sites

\section{References}

Carter G. \& Smith S. 2006. Safety Hazard Identification on Construction Projects. In Journal of construction engineering and management. February 2006. ASCE. p. 197-205.

Latvala, T. \& Pyykkönen, P. 2009. Teknotila-hankkeen tuloksia. 20.08.2009. Henkilökohtainen tiedonanto.

MMM 2013. Maa- ja metsätalousministeriö. Maaseudun kehittäminen / Maaseudun rakentaminen / Maatilarakentaminen.

http://www.mmm.fi/fi/index/etusivu/maaseudun_kehittaminen/maaseu turakentaminen/maatilarakentaminen.html

Mäkelä, T. 2006. Pientalojen aluerakentamisen työturvallisuus. VTT tutkimusraportti VTT-R-07902-06.

Oinonen, K. \& Aaltonen, M. 2007. Työterveys ja työturvallisuus tuottavuustekijänä. Työtapa-turmien aiheuttamat kustannukset. Työturvallisuuden merkitys työpaikkojen tuottavuuteen -projektin tutkimusosio 2:n loppuraportti Työsuojelurahastolle.

Tilastokeskus 2013. Tilastokeskus. Verkkopalvelut /Suomi lukuina / rakentaminen.

http://www.stat.fi/tup/suoluk/suoluk_rakentaminen.html

Työturvallisuuslaki 2003. Työturvallisuuslaki 738/2002. http://www.finlex.fi/fi/laki/smur/2002

VnA 2009. Valtioneuvoston asetus rakennustyön turvallisuudesta. http://www.finlex.fi/fi/laki/smur/2009/ 